\title{
LA FACULTAD DE ATRACCIÓN COMO MECANISMO EXCEPCIONAL DE ALTERACIÓN DEL REPARTO DE COMPETENCIAS JURISDICCIONALES EN MATERIA PENAL: UN ESTUDIO DE LAS REFORMAS DE LEGISLACIÓN MEXICANA DE 2012 Y 2013'
}

\author{
The Removal of Criminal Cases to the Federal \\ Jurisdiction: A Study of the Mexican Reforms \\ of 2012-2013
}

\author{
MIGUEL BELTRÁN DE FELIPE² \\ Universidad de Castilla-La Mancha \\ miguel.beltran@uclm.es
}

Cómo citar/Citation

Beltrán de Felipe, M. (2016).

La facultad de atracción como mecanismo excepcional de alteración del reparto de competencias jurisdiccionales en materia penal: un estudio de las reformas de legislación mexicana de 2012 y 2013. Anuario Iberoamericano de Justicia Constitucional, 20, 33-68. doi: http://dx.doi.org/10.18042/cepc/aijc.20.02

\section{Resumen}

El artículo describe y analiza, desde el punto de vista del derecho comparado, pero con particular énfasis en México, uno de los más relevantes fenómenos de conflicto y/o de alteración del reparto de las competencias entre los órganos del poder judicial en materia penal. Se trata de la llamada facultad de atracción, consistente en que un caso pasa de la jurisdicción territorial (estatal o provincial) a la jurisdicción central (federal). La finalidad del trabajo es presentar una especie de mapa de cómo algunos países regulan y resuelven las posibles conflictos o colisiones de competencia entre los ámbitos de los distintos tribunales o de las distintas jurisdicciones penales, y de si en los países federales como México (en las reformas llevadas a cabo en 2012 y 2013 para la represión penal de los delitos contra periodistas), se prevé o no, y en qué términos, el trasvase de casos de la jurisdicción estatal a la jurisdicción federal, esbozándose algunos criterios para esta facultad de atracción. 


\title{
Palabras clave
}

Competencia jurisdiccional penal; avocación; per saltum; facultad de atracción; conflicto de jurisdicción; conexidad; crímenes contra periodistas.

\begin{abstract}
The article deals with the main situations in which criminal jurisdictions can collide at national level, or in which the courts resolve the jurisdictional conflicts which arise. It focuses mainly on Mexico, and it uses a comparative approach. It analyzes the most common conflict, that is: the possibility of removing or remanding a case from local or State Courts to Federal Courts. The article aims at mapping the main problems posed that this type of conflict in the criminal jurisdictions, and at pointing out what the solutions have been in different countries. It also tries to establish some minimum standards regarding the capacity of federal authorities to remove a particular case from state or local Courts, particularly in Mexico, after the procedural reforms of 2012 and 2013 to punish the crimes against freedom of expression and particularly against journalists.
\end{abstract}

\section{Keywords}

Criminal jurisdiction; certiorari; removal; remand; per saltum; conflicts of jurisdiction; crimes against journalists.

1 Este trabajo tiene su origen en un informe realizado para Freedom House México en 2012, con ocasión de la participación de esta organización en los trabajos preparatorios de la legislación de desarrollo del art. 73, fracción XXI, de la Constitución mexicana en lo relativo a los delitos cometidos contra periodistas. Agradezco la confianza en mí depositada, y las observaciones realizadas por Mariclaire Acosta, directora de Freedom House México; Ricardo Sepúlveda, director general de Políticas Públicas de Derechos Humanos de la Secretaría de Gobernación, y por Jaime Rochín, del Centro Jurídico para los Derechos Humanos. El trabajo está actualizado al verano de 2014, y por tanto incluye la normativa de desarrollo a que me acabo de referir (esencialmente el nuevo art. 10 del Código Federal de Procedimientos Penales, reformado en 2013). Las opiniones que se vierten son imputables únicamente al autor, no a Freedom House México.

2 Catedrático de Derecho Administrativo en la Universidad de Castilla-La Mancha. Ha sido asimismo profesor visitante en la Universidad de Georgetown (EEUU). También tiene experiencia en el Ministerio de la Presidencia de España, como letrado del Tribunal Constitucional de España y como Fulbright Congressional Fellow en la Cámara de Representantes del Congreso de los Estados Unidos. También ha sido consultor y asesor de distintas administraciones y organizaciones, particularmente en la Organización de los Estados Americanos. 


\section{SUMARIO}

I. INTRODUCCIÓN. II. LA FACULTAD DE ATRACCIÓN EN EL DERECHO COMPARADO. III. PROBLEMAS QUE PLANTEA LA FACULTAD DE ATRACCIÓN Y POSIBLES CRITERIOS PARA RESOLVERLOS: 1. Problemas teóricos y de constitucionalidad de la facultad de atracción; 2. Sistematización de algunos posibles criterios para el ejercicio de la facultad de atracción. IV. REGLAS GENERALES DE LA CONEXIDAD Y DE LA COMPETENCIA POR CONEXIÓN: REFERENCIAS DE DERECHO COMPARADO. V. LA FACULTAD DE ATRACCIÓN TAL Y COMO RESULTA DE LA REFORMA CONSTITUCIONAL MEXICANA DE 2012, REGLAMENTADA EN EL AÑO 2013 CON LA MODIFICACIÓN DEL ART. 10 DELCÓDIGO FEDERAL DE PROCEDIMIENTOS PENALES: 1 . El ejercicio de la facultad de atracción como competencia discrecional; 2. El art. 10 del Código Federal de Procedimientos Penales como supuesto de atracción sin conexidad. VI. BIBLIOGRAFÍA.

\section{INTRODUCCIÓN}

La finalidad de este artículo es hacer un recorrido por una de las principales alteraciones en las reglas del reparto de las competencias entre los órganos del poder judicial en materia penal: la llamada facultad de atracción. El enfoque se centra en la legislación procesal de México, país federal en el que existe la atracción de un caso por las autoridades federales (así como la avocación de casos y asuntos por parte de los órganos jurisdiccionales superiores, mecanismo este que se intentará diferenciar de la facultad de atracción).

Comenzaré (apartado II) exponiendo la denominada facultad de atracción desde la perspectiva del derecho comparado, diferenciándola de otras técnicas como la avocación y centrándola en los modelos federales con dualidad jurisdiccional penal, para a continuación (apartado III) detenerme en los problemas que la facultad de atracción presenta para la teoría procesal y para las reglas constitucionales. En el apartado IV estudiaré - desde un punto de vista comparatista - la cuestión de la conexidad. Finalmente, en el apartado $V$ me detendré en la facultad de atracción tal y como resulta de la reforma del 
art. 10 del Código Federal de Procedimientos Penales (en adelante CFPP) de México llevada a cabo en el año 2013.

Como advertencia previa, haré una precisión conceptual. En México la locución «facultad de atracción» puede aludir indistintamente a dos cosas. Por un lado, a la posibilidad de que por vía de amparo o de apelación, la SCJN seleccione de oficio casos, avocándose su conocimiento. Es lo que establecen los arts. 105 III, para la apelación ${ }^{3}$, y 107, fracciones V, inciso d), segundo párrafo y VIII, inciso b), segundo párrafo, de la Constitución mexicana, para el amparó . Por otro lado, estaría la facultad de atracción propiamente dicha, o sea: la posibilidad de que las autoridades (la Procuraduría federal) decretasen que un determinado delito, que correspondería investigar y enjuiciar a un Estado, pase a la jurisdicción federal como consecuencia de las reformas constitucionales y legales de los años 2012 y 2013 (art. 73, fracción XXI de la Constitución y art. $10 \mathrm{CFPP})$. En el presente trabajo no me detendré en lo primero (o sea en el salto jerárquico de un caso de un órgano judicial inferior a otro superior, o avocación, denominada también en Argentina "per saltum» de oficio $)^{5}$.

3 «La Suprema Corte de Justicia de la Nación conocerá, en los términos que señale la ley reglamentaria, de los asuntos siguientes: [...] De oficio o a petición fundada del correspondiente Tribunal Unitario de Circuito o del Ejecutivo Federal, por conducto del Consejero Jurídico del Gobierno, así como del Fiscal General de la República en los asuntos en que intervenga el Ministerio Público, podrá conocer de los recursos de apelación en contra de sentencias de Jueces de Distrito dictadas en aquellos procesos en que la Federación sea parte y que por su interés y trascendencia así lo ameriten».

4 «La Suprema Corte de Justicia, de oficio o a petición fundada del correspondiente Tribunal Colegiado de Circuito, o del Procurador General de la República, podrá conocer de los amparos en revisión, que por su interés y trascendencia así lo ameriten». Este precepto es desarrollado por los arts. 40 y 85 de la ley de amparo (tras sus reformas de 2013 y 2014).

5 Algunas Constituciones mencionan y prohíben expresamente la avocación. Por ejemplo, el art. 139 de la Constitución del Perú (1993) prohíbe en su apartado $2^{\circ}$ a cualquier autoridad avocarse causas judiciales (pero esto no es la prohibición del per saltum, sino la prohibición de que la autoridad gubernativa se atribuya funciones jurisdiccionales), y establece en su apartado $3^{\circ}$ que «ninguna persona puede ser desviada de la jurisdicción predeterminada por la ley, ni sometida a procedimiento distinto de los previamente establecidos, ni juzgada por órganos jurisdiccionales de excepción ni por comisiones especiales creadas al efecto, cualquiera sea su denominación». Esta regla arranca del constitucionalismo histórico, ya que las constituciones del siglo XIX pretendían eliminar o limitar la discrecionalidad del rey o del Parlamento en relación con el poder judicial. 


\section{LA FACULTAD DE ATRACCIÓN EN EL DERECHO COMPARADO}

Como se acaba de apuntar, la facultad de atracción consiste en que un delito que debería en principio estar sometido al derecho penal local o estatal o regional, y ser enjuiciado por los tribunales correspondientes, pase a estar sometido al derecho penal federal y a ser enjuiciado por los tribunales federales, y ello por una decisión ad hoc de las autoridades judiciales o eventualmente gubernativas. La atracción es, pues, una alteración «singular» o ad hoc, que únicamente puede darse, como es lógico, en aquellos países federales que tienen dos ámbitos normativos diferenciados en materia penal. Es decir, dos o más códigos penales. Por esta razón, no se puede dar en países como Alemania, Argentina, Suiza, Austria, Brasil, Bélgica o Rusia. Se trata evidentemente de países federales, donde el poder y, en teoría, la soberanía están repartidos entre la federación y los Estados (o provincias o cantones o Länder), pero no tienen dualidad jurisdiccional penal porque sólo hay un Código Penal.

Centrada así la noción de la facultad de atracción, sólo puede existir en países con estructura federal y con dualidad de jurisdicciones penales. Estos países son esencialmente México y los EE. UU. ${ }^{6}$

\footnotetext{
Argentina es un modelo distinto: no hay "federalismo» penal, porque sólo hay un código penal para la toda la nación, pero en cambio «las provincias tienen su propia Constitución y han conservado para sí, sin delegar en el poder federal, la organización y el funcionamiento de sus poderes constituidos como es el caso del Poder Judicial (art. 5 y 122, Constitución Nacional)» (Haro, 2001). De este modo, existe un único código penal, pero cada una de las 23 provincias tiene su propia organización de la justicia y su propia legislación procesal penal, y existe un reparto de jurisdicciones en función del tipo de delito — delitos que, reitero, son definidos de manera uniforme para toda la nación_- Luego las leyes procesales territoriales son «soberanas» para determinar el enjuiciamiento de ciertos delitos ante los tribunales provinciales, sin que esté previsto el «salto» a los tribunales federales. Sin embargo, la jurisprudencia de la CSJN ha establecido que también hay per saltum desde la jurisdicción provincial a la jurisdicción federal en materia de constitucionalidad - lo cual fue interpretado en la década de 1980 de manera restrictiva, es decir, requiriendo que el asunto transite todas las instancias locales y provinciales antes de llegar a la CSJN-. De nuevo «una solución contraria, más permisiva, importaría lisa y llanamente un avasallamiento a las autonomías provinciales y constituiría una verdadera 'intervención federal' en el ejercicio del poder judicial provincial» (op. cit., p. 187). El autor, citando a Bidart, duda incluso de la constitucionalidad de este per saltum federal: «En tal caso el Poder Judicial de la Nación absorbería inconstitucionalmente, fagocitaría una causa que se
} 
Lo primero que hay que decir es que la facultad de atracción es tendencialmente una quiebra del principio del federalismo. En países de estructura federal plena (es decir, con dualidad de jurisdicciones y de códigos penales y con dual sovereignty) como son México y los EE. UU., la posibilidad de que un delito que es por naturaleza estatal sea enjuiciado como si se tratase de un delito federal debe considerarse como algo extraño, y a priori incompatible con las reglas esenciales del federalismo.

Por eso en los EE. UU. no existe la facultad de atracción, en virtud de la noción de «doble soberanía». A lo largo de su articulado7, la Constitución menciona sólo tres delitos federales (traición, piratería y falsificación de moneda) y permite al Congreso establecer tribunales inferiores al Tribunal Supremo (que es creado por la Constitución misma en el art. III, sección 1a). El resto del derecho penal ordinario queda en manos de los estados y sus respectivos códigos penales. Con el paso del tiempo, la jurisdicción penal federal ha crecido mucho, hasta el punto de que hoy no se sabe a ciencia cierta cuantos delitos federales existen ${ }^{8}$. Suele tratarse de delitos en materia informática, migratoria, lavado de dinero, tráfico de drogas, patentes y marcas y propiedad intelectual, fraudes crediticios y contables, robos cualificados (obras de arte, etc.), crimen organizado, corrupción de funcionarios, usurpación de identidad, medio ambiente, etc. Los delitos federales son investigados por las autoridades policiales federales (el FBI) y la acusación la ejercen los fiscales federales (US Attorneys) ante tribunales penales federales. Existen muchos casos de colisión entre los delitos federales y los delitos estatales, que se resuelven por los tribunales mediante las técnicas de removal y de remand: el acusado de un delito estatal puede - con muchas limitaciones, para que no abuse de esta facultad- plantear que el caso sea llevado a la jurisdicción federal (removal). Y viceversa: un caso a priori federal puede ser remanded (devuelto) a la juris-

encuentra en plena tramitación judicial según el Código Procesal local y ante los tribunales competentes de la Provincia” (loc. cit).

7 El art. I, sección 8 ${ }^{\text {a }}$, de la Constitución de 1787 señala que "The Congress shall have Power [...] 6. To provide for the punishment of counterfeiting the Securities and current Coin of the United States [... 9. To constitute Tribunals inferior to the Supreme Court [...] 10. To define and punish Piracies and Felonies committed on the high Seas, and Offences against the Law of Nations». El art. III, sección 2a , regula la extensión de la jurisdicción federal.

8 Se han hecho cálculos que sitúan el número de delitos federales entre 3500 y 4500. Las leyes penales federales ocupan cerca de 27000 páginas de la recopilación legislativa federal (Federal Code), esencialmente en su título 18, dedicado a los tributos, al uso de armas, etc. 
dicción estatal. En cualquier caso, son decisiones judiciales y no gubernativas, similares a los conflictos de competencia y de jurisdicción.

En los EE. UU. pueden darse situaciones en los que la misma conducta es constitutiva de delito estatal y de delito federal (concurrentjurisdiction). En estos supuestos, en virtud de la "doble soberanía» no prima necesaria y automáticamente una jurisdicción sobre la otra, de manera que normalmente ambas jurisdicciones pueden enjuiciar. Así, habrá dos procesos penales distintos por los mismos hechos, pero al ser delitos distintos y pertenecientes a dos jurisdicciones distintas, no se considera en principio que ello vulnere el principio non bis in idem (doublejeopardy). Con el fin de evitar problemas de este tipo, y de concentrar la acusación en un único proceso, los fiscales estatales y federales colaboran en la selección de una de las dos jurisdicciones. Pero ello es una opción meramente práctica y no responde a una exigencia del sistema. $Y$ de hecho no es infrecuente que un ciudadano que vulnere simultáneamente el código penal estatal y las leyes penales federales o las leyes penales de dos estados, pueda ser juzgado (y ser condenado o ser absuelto) en las dos jurisdicciones.

En definitiva: en los EE. UU. se mantiene la "doble soberanía» (dual sovereignty) y no existe facultad de atracción, mientras que en el vecino México la propia Constitución sí lo permite.

En todo caso, como hipótesis, la facultad de atracción se puede producir de muchas maneras:

- por decisión de las autoridades federales (que es lo que sucede normalmente) o bien por decisión de las autoridades estatales (no suele suceder, pero sí pueden instar a aquellas a que ejerzan la facultad de atracción);

- por decisión de la Fiscalía o bien por decisión de los tribunales;

- de oficio o bien a petición de alguna de las partes personadas en la causa penal (incluyendo el fiscal);

- de manera discrecional (es decir, no reglada) o bien por causas tasadas;

- pudiendo ser recurrida o bien sin que quepa recurso alguno;

- con regulación constitucional o bien sin regulación constitucional (es decir, con previsión únicamente a nivel legislativo).

Idealmente, lo más acorde con la teoría constitucional del federalismo sería:

- que la facultad de atracción estuviese prevista en la Constitución;

- que fuesen los tribunales (y no el Gobierno, o la Fiscalía) quien tuviese la última palabra respecto de si un delito debe o no transitar del ámbito estatal al ámbito federal; 
- que, una vez judicializada la decisión, fuesen los tribunales federales quienes decidiesen, y no los tribunales estatales;

- que en esta decisión se oyese a las partes personadas y a las autoridades federales (se supone que proclives a la atracción) y a las autoridades estatales (las cuales es verosímil que quieran preservar la integridad de su jurisdicción y mantener el caso en su propio ámbito);

- que esta decisión se aplique no a delitos uno por uno considerados, sino a categorías homogéneas de delitos;

- que esta decisión se tomase conforme a criterios reglados y preestablecidos en la ley, evitando un excesivo margen de discrecionalidad en la decisión.

En el apartado $\mathrm{V}$ analizaré los criterios establecidos para la facultad de atracción, en la reforma del CFPP, operada por el Decreto de 25 de abril de 2013, con ocasión del desarrollo de la reforma constitucional del art. 73, fracción XXI, de la Constitución Federal relativo a los delitos contra la libertad de expresión.

\section{PROBLEMAS QUE PLANTEA LA FACULTAD DE ATRACCIÓN Y POSIBLES CRITERIOS PARA RESOLVERLOS}

\section{PROBLEMAS TEÓRICOS Y DE CONSTITUCIONALIDAD DE LA FACULTAD DE ATRACCIÓN}

Según se dijo anteriormente, en el ámbito penal la facultad de atracción representa una excepción al principio del federalismo. Por eso los EEUU no la contemplan, y además los "puentes» que en ese país existen entre las jurisdicciones federal y estatal son muy limitados y están judicializados: se pretende preservar la dualidad jurisdiccional, que se considera un elemento esencial del sistema.

En realidad, no sólo la facultad de atracción es una excepción o un elemento extraño al sistema federal. Ya se dijo más atrás que en los países no federales también la avocación o el per saltum de oficio deben considerarse algo excepcional y tendencialmente incompatible con el sistema. En efecto, que un órgano judicial superior decida «atraer» (de oficio o a petición de la fiscalía) un asunto desde la jurisdicción estatal hacia la jurisdicción federal, no encaja bien con los siguientes principios procesales o constitucionales: la independencia del poder judicial, la improrrogabilidad de la jurisdicción, el principio del juez predeterminado por la ley o el principio del juez natural y, finalmente, el principio de seguridad jurídica. Veámoslos. 
a) La independencia del poder judicial

Me parece bastante evidente que si se permite a las partes o al Ministerio Fiscal solicitar al tribunal sentenciador que renuncie a su jurisdicción y forzar su pronunciamiento sobre la conveniencia de avocar o de atraer, entonces la independencia judicial puede quedar indirectamente en entredicho. La jurisdicción no es disponible para las partes y cuando a estas se les permite no sólo discutirla, sino pedirle al tribunal sentenciador (o al Tribunal Supremo) que libre y discrecionalmente se salte las reglas de reparto jurisdiccional, entonces el juzgador pierde en alguna medida independencia respecto de la ley, única fuente de su legitimidad, y se vuelve más dependiente respecto de la parte que interpreta (libremente) las reglas de competencia.

En realidad el problema más importante no sería la independencia de los tribunales frente a sujetos «ajenos» a ella (las partes, la Fiscalía, el Gobierno o eventualmente la prensa), sino frente a sí misma, es decir, preservar la competencia de los tribunales inferiores frente a las intromisiones del Tribunal Supremo, con riesgo de incurrir en el «voluntarismo competencial» y en el "activismo desaforado» que denuncia Haro (2001).

En el caso mexicano (en la facultad de atracción respecto de los delitos contra la libertad de expresión regulada en la reforma del año 2013), el menoscabo a la independencia judicial podría incluso llegar a considerarse aun mayor, puesto que no es el juez quien decide ejercer dicha facultad sino que lo decide la Fiscalía, y las autoridades judiciales (federales o estatales) parece deban necesariamente aceptar dicha decisión. Es una autoridad gubernativa quien decide la competencia jurisdiccional, lo cual resulta verdaderamente infrecuente - es infrecuente que un órgano no jurisdiccional como la Fiscalía decida cuál es la jurisdicción (la Federal o la estatal) competente para conocer de un determinado caso.

b) La improrrogabilidad de la jurisdicción

Este principio lo establecen expresamente en varias Constituciones y leyes, por ejemplo en el art. 40 del Código Procesal Penal de Guatemala ( $L a$ competencia penal es improrrogable») o en España en los arts. 9 de la Ley Orgánica del Poder Judicial («1. Los Juzgados y Tribunales ejercerán su jurisdicción exclusivamente en aquellos casos en que les venga atribuida por esta u otra Ley [...] 6. La jurisdicción es improrrogable») y 8 de la Ley de Enjuiciamiento Criminal de España («La jurisdicción criminal es siempre improrrogable») (Rizo Gómez, 2006). Otros países afirman este principio de manera menos tajante, pues lo someten a posibles excepciones. Por ejemplo, el art. 20 del Código de Procedimiento Penal de Ecuador, del año 2000: «La competencia en materia penal es improrrogable, excepto en los casos expresamente señalados en la ley», o el art. 9 del Código de Procedimiento Penal de Chile, que 
prohíbe la alteración de la jurisdicción por voluntad de las partes (y por consiguiente parece autorizarla si se produce por ley o si la dispone el tribunal): «La competencia criminal no puede, en caso alguno, ser prorrogada por la simple voluntad de las partes». natural

c) El principio del juez predeterminado por la ley o principio del juez

Considerándolos a los efectos de este trabajo como equivalentes, aquél es elevado a la categoría de derecho fundamental en España (art. 24.2 de la Constitución de 1978: «todos tienen derecho al Juez ordinario predeterminado por la Ley»), y lo mismo sucede en el Perú: el art. 139.3 de la Constitución establece: «Ninguna persona puede ser desviada de la jurisdicción predeterminada por la ley, ni sometida a procedimiento distinto de los previamente establecidos, ni juzgada por órganos jurisdiccionales de excepción ni por comisiones especiales creadas al efecto, cualquiera sea su denominación». Por su parte, el principio del juez natural ha sido interpretado de manera casi unánime como está incluido en el art. 8 de la Convención Americana de Derechos Humanos de 1969:

1. Toda persona tiene derecho a ser oída, con las debidas garantías y dentro de un plazo razonable, por un juez o tribunal competente, independiente e imparcial, establecido con anterioridad por la ley, en la sustanciación de cualquier acusación penal formulada contra ella, o para la determinación de sus derechos y obligaciones de orden civil, laboral, fiscal o de cualquier otro carácter.

Constituciones y leyes americanas recogen prácticamente este mismo contenido, pero no todas lo denominan expresamente «juez natural» —lo mismo que la $\mathrm{CADH}$, que no emplea dicha locución en ningún momento-. Véanse, por ejemplo, el art. 29 de la Constitución colombiana: «El debido proceso se aplicará a toda clase de actuaciones judiciales y administrativas. Nadie podrá ser juzgado sino conforme a leyes preexistentes al acto que se le imputa, ante juez o tribunal competente y con observancia de la plenitud de las formas propias de cada juicio»; el Código Procesal Penal de El Salvador (Decreto 733): «Principio de legalidad del proceso y garantía del juez natural. Art. 2: Toda persona a la que se impute un delito o falta será procesada conforme a leyes preexistentes al hecho delictivo de que se trate y ante un juez o tribunal competente, instituido con anterioridad por la ley»; el Código Procesal Penal de Costa Rica (art. 3): «Juez natural. Nadie podrá ser juzgado por jueces designados especialmente para el caso. La potestad de aplicar la ley penal corresponderá sólo a los tribunales ordinarios, instituidos conforme a la Constitución y la ley», y el Código Procesal Penal de Argentina de 1991 (Art. 
1): «Nadie podrá ser juzgado por otros jueces que los designados de acuerdo con la Constitución y competentes según sus leyes reglamentarias»?.

d) El principio de seguridad jurídica

Es este un principio más reciente, que se aplica no sólo al derecho procesal sino en general a todo el Derecho, y que recoge por ejemplo el art. 9.3 de la Constitución española:

La Constitución garantiza el principio de legalidad, la jerarquía normativa, la publicidad de las normas, la irretroactividad de las disposiciones sancionadoras no favorables o restrictivas de derechos individuales, la seguridad jurídica, la responsabilidad y la interdicción de la arbitrariedad de los poderes públicos.

Es claro que cuando el acusado de un delito o, en general, las partes en un asunto penal, no conoce qué tribunal le va a juzgar porque la causa pueda ser avocada por un tribunal superior, tiene mucha menos seguridad jurídica que cuando las reglas de reparto competencial son indisponibles.

Como más adelante se dirá, en la reforma mexicana de 2013 sobre los delitos contra la libertad de expresión lo determinante fue la necesidad de dar respuesta al enorme incremento de la violencia contra periodistas, y ello posiblemente explique la adopción de medidas no muy ortodoxas desde el punto de vista de la teoría procesal.

9 Naturalmente, las vertientes y contenidos de este «juez natural» o «juez predeterminado» no son las mismas en cada país. En España el Tribunal Constitucional (por ejemplo, recientemente en la sentencia 177/2014) ha caracterizado el derecho al juez ordinario predeterminado por la ley del art. 24.2 de la Constitución diciendo «se requiere que el órgano judicial haya sido creado por una norma legal invistiéndolo de jurisdicción y competencia con anterioridad al hecho motivador de la actuación o proceso judicial; que su régimen orgánico y procesal no permita calificarlo de órgano especial o excepcional; que se haya procedido, en casos de sustitución, conforme a una interpretación de las normas sobre atribución de competencias a los órganos jurisdiccionales que no suponga una manipulación manifiestamente arbitraria de las reglas legales sobre atribución de competencias; o, en fin, que no se haya dado una decisión que suponga despojar de la potestad de jurisdicción al órgano judicial - o en su caso al titular de éste - que la ostentaba, contra el texto claro e inequívoco de la ley». Al respecto en España hay bastante bibliografía: por no citar más que alguna de los últimos años, veánse Córdoba Castroverde (2000), Escalada López (2007 y 2011) y Rizo Gómez (2014). 


\section{SISTEMATIZACIÓN DE ALGUNOS POSIBLES CRITERIOS PARA EL EJERCICIO DE LA FACULTAD DE ATRACCIÓN}

Para que la facultad de atracción pueda encajar sin demasiada dificultad en la teoría del derecho procesal y en la teoría del federalismo deberían a mi juicio concurrir tres elementos fundamentales.

a) El primero, y más importante de ellos, es que la Constitución lo permita. Si la Constitución consagra un sistema federal con dualidad de jurisdicciones, parece obligado entender que no habilita a una de las partes (la federación o los estados) para saltarse una regla estructural así de importante. Es lo que ocurre en los EE. UU.: la Constitución establece - bien es cierto que de manera muy esquemática - el dualismo jurisdiccional, y no menciona la posibilidad de atracción, de modo que se podría cabalmente interpretar que dicha atracción no es posible ${ }^{10}$ y que, consecuentemente, la ley que lo autorizase sería inconstitucional.

b) El segundo elemento sine qua non sería que la facultad de atracción estuviese no sólo prevista o permitida en la Constitución, sino además regulada en la ley. A falta de habilitación legal, no parece posible alterar el reparto jurisdiccional penal entre la federación y los estados ${ }^{11}$. Es más: posiblemente no sea suficiente con una mera previsión legal, sino que la facultad de atracción deba estar sometida a reglas claras establecidas en la ley. Con el fin de que no se convierta en una potestad discrecional de las autoridades de la federación, susceptible de hacer pasar a la jurisdicción federal cualquier caso penal o eventualmente viceversa, la facultad de atracción debe estar prevista en la ley con un mínimo de certeza.

El tercer y último elemento, tal vez el menos importante, sería que la decisión no la tomasen las autoridades gubernativas (federales o estatales), sino que fuese el propio poder judicial quien así lo decidiese. Sin duda,

10 En relación con el carácter improrrogable de la jurisdicción penal (y, por tanto, en un contexto distinto al del federalismo), el art. 40 del Código Procesal Penal de Guatemala (Decreto 51-92) sí permite la alteración de la jurisdicción pero únicamente cuando la Constitución así lo autorice: «La competencia penal es improrrogable. La competencia territorial de un tribunal no podrá ser objetada ni modificada de oficio una vez iniciado el debate; se exceptúan aquellos casos reglados por una disposición constitucional que distribuye la competencia entre distintos tribunales».

11 En Argentina el per saltum (tanto a pedido de parte como de oficio, y tanto a nivel únicamente federal como entre las jurisdicciones federal y estatal) es una creación esencialmente jurisprudencial, sin respaldo constitucional, lo cual fue criticado por la mayoría de los autores. 
se puede y se debe permitir que las partes o el fiscal introduzcan en el debate procesal la propia competencia del órgano judicial, sometiendo a la consideración de éste la corrección del reparto y ubicación del asunto. No obstante, parece que la decisión final debería ser tomada por el juez o tribunal y no por una autoridad gubernativa como la Fiscalía.

A continuación voy a detenerme en los elementos segundo y tercero (el primero, referido a la necesidad de previsión constitucional, me parece bastante evidente y no necesitado de mayor comentario).

En relación con la concreción por ley de los casos en los que proceda la facultad de atracción, tales reglas deben precisar ante qué casos penales puede ejercerse, qué autoridad está legalmente habilitada para tomar esa decisión, qué mecanismos de control existen que impidan que se abuse de la atracción, qué efectos tiene sobre las partes, etc. En realidad aquí el legislador estaría ante una disyuntiva:

- o bien limitarse a prever o permitir sin más la facultad de atracción, dejando su concreción o desarrollo en manos de los Tribunales o de la Fiscalía,

- o bien dar un paso más y regular con un cierto detalle los elementos y condiciones para su ejercicio (como si fuesen las causales de un recurso o acción).

De este modo, dependiendo de qué alternativa se adopte a la hora de reglamentar la facultad de atracción, esta se configuraría como una potestad previsible y de mera aplicación automática de las reglas o, por el contrario, quedaría prácticamente como una competencia discrecional. Como esta segunda posibilidad me parece descartable, por la razón ya mencionada de que dejaría en manos de la federación el principio mismo del federalismo, es conveniente configurar las reglas de la facultad de atracción de manera que pueda delimitar, hasta donde resulte posible o razonable, las posibilidades de selección de casos que puedan ser atraídos. Esta delimitación podría hacerse, al menos, de estas tres posibles maneras:

- estableciéndola como una competencia reglada (de uso obligatorio o automático cuando se den las circunstancias legalmente previstas) en lugar de como una potestad más o menos discrecional;

- estableciendo que se aplicará con carácter general para grupos de delitos predeterminados en lugar de para casos más o menos libremente seleccionados dentro de esos grupos de delitos; 
- si no se quiere prever que se aplique a categorías enteras de delitos, y se deja a la facultad de la autoridad federal, entonces se pueden establecer criterios lo más objetivos posible para el ejercicio de la facultad de atracción, en lugar de dejarlo al mero criterio de la autoridad federal.

En cuanto a lo primero (discrecionalidad v. potestad reglada), es a priori posible que la facultad de atracción se configure como eso, como una «facultad» (o simple posibilidad), o bien que se configure como algo obligatorio que deba necesariamente ser ejercido por las autoridades federales cuando se den las circunstancias previstas. Es una disyuntiva clásica en el derecho público: la que opone las potestades regladas (aplicación automática, sin posibilidad o margen de decisión, y con una única solución posible) a las potestades discrecionales (margen de decisión que compete a quien decide, con dos o más soluciones a priori válidas o posibles). La existencia de conceptos jurídicos indeterminados enturbia esta distinción ${ }^{12}$. Así lo reconocen Báez y Cienfuegos (2009: 1216), quienes al comentar la facultad de atracción del art. 189 bis de la LOPJF, señalan que los únicos criterios allí establecidos («importancia y trascendencia del caso») «son de no fácil definición [...] y difícilmente puede preceptuarse algo al respecto en una norma reglamentaria». Es decir: estos autores reconocen que la ley no puede o no debe ir más allá, y que la concreción de estos criterios debe realizarse por vía jurisprudencial o pretoriana.

Creo razonable sostener que el trasvase de casos de la jurisdicción estatal a la jurisdicción federal sólo encajaría en el sistema cuando su ejercicio no se configurase como una competencia discrecional. Si se tratase de una competencia discrecional, nada menos que una regla estructural de los Estados federales (la existencia de dos jurisdicciones separadas, federal y estatal) quedaría en manos de la libre apreciación de las autoridades federales. Regular esta facultad simplemente con el verbo "podrá», como hace el art. 73, fracción XXI, de la Constitución Federal mexicana, y no establecer ulteriores reglamentaciones, introduciría un elemento de discrecionalidad tendencialmente problemático dentro del sistema federal. Más adelante examinaremos en qué medida la reglamentación dada en la reforma del año 2013 relativa a los deli-

12 Por ejemplo, que la facultad de atracción se ejerza en casos de «interés general» o de «alteración del orden público», a priori determina que sólo haya una solución (o hay interés general o no lo hay), aproximándose así a la potestad o decisión reglada. Sin embargo, la evidente presencia de un margen de interpretación, la falta de criterios sobre cuándo se da o no se da ese concepto, así como la dificultad del control judicial de la decisión son factores que indudablemente lo aproximan a la decisión discrecional. 
tos contra la libertad de expresión limita mucho, poco o nada la discrecionalidad de la decisión.

En cuanto a lo segundo (atracción para grupos de delitos preestablecidos v. atracción para casos concretos), se trata de algo estrechamente conectado con lo que se acaba de señalar. Me parece muy conveniente que la facultad de atracción se configure como una potestad que las autoridades federales empleen casos predeterminados en lugar de sin ninguna mención respecto de su ámbito de aplicación. También existiría algo así como un término medio: que dentro de casos predeterminados, las autoridades puedan seleccionar más o menos libremente algunos de ellos.

Por orden de su mejor encaje con la teoría constitucional y con los principios procesales mencionados en el apartado anterior, las opciones serían:

a) Que la ley prevea la aplicación de la facultad de atracción para grupos completos de delitos. En este caso en realidad no hay "facultad de atracción» sino federalización completa. Porque la autoridad federal carecería de todo margen de maniobra para "atraer» casos, en la medida en que los casos predeterminados por la ley caerían automáticamente dentro del ámbito federal, y estaríamos ante un modelo completamente distinto: sería el enjuiciamiento en bloque de ciertos delitos por instancias centrales o federales, sin margen de elección o «atracción» para las autoridades federales.

b) Que la ley prevea la aplicación de la facultad de atracción para ciertos casos seleccionados dentro de grupos completos de delitos. La selección se haría en función de criterios como la "conexidad» predeterminada: algunos casos penales caerían en la jurisdicción federal y otros no, pero la distinción se haría conforme a criterios relativamente objetivos.

c) Que la ley prevea la aplicación de la facultad de atracción sin referencia ninguna a un tipo u otro de delitos, o conforme a un criterio de conexión amplio y casi discrecional (por ejemplo atendiendo a su «gravedad»o a su «trascendencia social» o a la «alarma social causada»).

Es el caso b) el que más interesa porque podría no ser suficiente establecer una regla como «en casos de conexión o conexidad el caso pasará a la jurisdicción federal», pues permite a priori cierto margen de apreciación por las autoridades federales. Sería interesante que la propia norma que establezca el principio de conexión defina lo que es «conexión» o «conexidad», o lo complete con ejemplos en los que se da dicha conexión. En el apartado siguiente, al hilo de la reforma mexicana de 2013, se mostrarán ejemplos de lo que las leyes procesales suelen entender por "conexidad» y se dirá si dicha reforma en realidad responde o no a la noción de conexidad. 
En términos de teoría jurídica, creo que la noción de «conexidad» debería ser como mucho un concepto jurídico indeterminado y nunca una facultad discrecional. Es decir, en ningún caso habría dos soluciones igualmente justas o correctas o legítimas o indiferentes para el Derecho, sino que el Derecho daría pautas o bien para la aplicación automática del elemento de conexidad (decisión reglada) o bien para la interpretación objetiva del concepto jurídico indeterminado. Es más, los criterios de determinación del concepto deberían venir establecidos en la ley misma, con el fin de evitar que la autoridad federal que lo interprete se «apodere» del concepto y lo use a su conveniencia. En el apartado próximo se analizará la noción de "conexión» o "conexidad».

Siendo estos dos (previsión constitucional y regulación legal) los elementos esenciales de la configuración constitucional de la facultad de atracción, debemos ahora considerar el tercero — que, me permito recordar, era la cuestión de a quién se atribuye la potestad o la facultad de atracción-. O también si las partes (o incluso las autoridades estatales) pueden impugnar la decisión ante una instancia independiente.

No parece discutible que la facultad de atracción se debe atribuir a las autoridades federales: son ellas quienes representan al conjunto de la nación, quienes están funcionalmente capacitadas para interpretar la necesidad de enjuiciamiento uniforme y a nivel federal de ciertos delitos. Ello no impide que se atribuya a las autoridades estatales la posibilidad de que soliciten de las autoridades federales que ejerciten la atracción; sería algo así como una inhibitoria.

Ahora bien, dentro de las autoridades federales, ¿̨qué poder o institución concreta debe poder ejercitar la facultad de atracción? Como antes se señaló, la alternativa es bastante clara: esta facultad puede estar atribuida o bien a un órgano del poder judicial federal (y por tanto independiente) o bien a un órgano del Gobierno federal o dependiente del mismo, como pueda ser el Ministerio Fiscal. En los casos de conflicto de competencias o de atribuciones quien resuelve el conflicto o controversia es siempre un órgano judicial (el Tribunal des Conflits en Francia, las SezioniUnite de la Corte di Cassazione en Italia, la Sala de Conflictos del Tribunal Supremo en España, las Cortes Supremas o Federales en los países americanos). Sin duda, las autoridades gubernativas como la Fiscalía participan en la decisión (se le da un trámite de informe o de alegaciones), y hasta pueden iniciar la controversia cuando considere que un asunto penal debe ser enjuiciado por las autoridades centrales y no por las territoriales. Es lo que sucede en Francia o España: cuando el Ministerio Público inicia la acusación en materia de terrorismo, y la inicia ante el juez centralizado y especializado, está calificando el delito como delito de terrorismo y, por ello, se dirige a aquel juez. Pero esta no es una decisión final. El juez puede discrepar de la calificación del fiscal y rechazar su competencia, 
devolviendo el asunto al juez «natural» competente por razón de la materia o del territorio.

En Francia o en España —al igual que ocurre en México con la facultad de atracción - la decisión de iniciar actuaciones en una u otra jurisdicción corresponde al Ministerio Fiscal. Como es natural, el poder de acusar incluye la decisión de calificar el delito y de que, en función de esa calificación, la acusación se residencie en la jurisdicción ordinaria o bien en la jurisdicción especializada (en Francia o en España), o en el caso de México, en la jurisdicción federal o bien en la jurisdicción estatal. En Francia y en España la decisión del fiscal está sometida a control judicial, es decir, el juez al que se dirige la acción penal puede no estar de acuerdo con la calificación hecha por el fiscal y rechazar su propia competencia. En ese caso es siempre la opinión jurisdiccional la que prevalece y se iniciarán los mecanismos de conflicto (conflicto negativo, conflicto positivo, inhibitoria, declinatoria, etc.). Lo que importa ahora destacar es que en países como Francia o España la última palabra la tiene el poder judicial y no el Ministerio Público: el juez es el dominus de su competencia y no está vinculado por la calificación de los hechos que haga el Ministerio Público.

De este modo, el Ministerio Público sometería al juez la decisión de atracción y este resolvería con audiencia de partes en un plazo breve. Cuando de la facultad de atracción se trata, como sucede en México, el asunto es de mayor trascendencia porque implica la aplicación de un principio estructural o constitucional cual es el del federalismo: en la teoría del federalismo los jueces son los garantes del federalismo mismo, de la dualidad jurisdiccional. Ello llevaría a que la decisión debiese ser adoptada por un tribunal independiente en lugar de por la autoridad gubernativa o la Fiscalía. Sin embargo, no ha sido esta la solución adoptada en la reforma del art. 10 del CFPP, operada en 2013: la facultad de atracción parece residenciarse enteramente en la Fiscalía, y nada se dice respecto del papel del juez, que parece quedar del todo vinculado a la decisión que se adopte por aquella ${ }^{13}$.

13 En México la discrepancia de las partes respecto de la atracción se plantea como un recurso de reconsideración ante la Procuraduría General (no como un recurso judicial), recurso que además se permite únicamente en caso de denegación de la atracción solicitada, no así cuando la Procuraduría decida ejercer la atracción. El Código Nacional de Procedimientos Penales, del año 2014, prevé igualmente la facultad de atracción (art. 21), pero sin mencionar la posibilidad de recurso de reconsideración. Esta omisión ha sido objeto de alguna iniciativa legislativa para remediarla (véase la iniciativa del proyecto de decreto que reforma el art.10 del Código Federal de Procedimientos Penales y que adiciona el art. 21 del Código Nacional de Procedimientos, suscrita en diciembre de 2014 por la diputada Miriam Cárdenas Cantú, del grupo parlamentario 
El otro extremo que considerar en relación con este asunto es el de la posibilidad o no de recurrir la decisión que se tome respecto de la atracción. Los sistemas de resolución de conflictos de competencia no suelen prever la posibilidad de recurso frente a las resoluciones que solventan dichos conflictos ${ }^{14}$ porque se entiende que el conflicto de competencias o de atribuciones plantea reglas objetivas o estructurales que no son susceptibles de ser recurridas. Es decir, las partes pueden ser oídas al respecto, pero no pueden interponer recurso. Ello se explica no sólo por el carácter objetivo, absoluto e indisponible de las reglas relativas a la competencia y a la jurisdicción de los tribunales, sino también por una razón mucho más práctica: porque si se diese recurso, los asuntos penales se dilatarían muchísimo dado que antes de poderse dictar sentencia de fondo las partes podrían estar interponiendo recursos y discutiendo la competencia y la jurisdicción durante años. Una vez adoptada la decisión por quien deba tomarla, no se revisaría.

\section{REGLAS GENERALES DE LA CONEXIDAD Y DE LA COMPETENCIA POR CONEXIÓN: REFERENCIAS DE DERECHO COMPARADO}

En derecho penal la regla general es que para cada delito que conozcan los tribunales debe existir un proceso. La conexión o conexidad es una excepción a esta regla, ya que pueden darse casos en los que, debido a circunstancias establecidas en la ley, el juez o tribunal enjuicie no un sólo delito o un solo hecho, sino varios delitos o varios hechos. El juez «atrae» hacia sí otros hechos o delitos que están lógica y sustantivamente relacionados con el hecho o delito principal, o al que la ley atribuye prevalencia a efectos de la atribución de competencia jurisdiccional.

del PRI: http://sil.gobernacion.gob.mx/Archivos/Documentos/2014/12/asun_3192414_2 0141222_1419267199.pdf).

14 El art. 36 del Código Federal de Procedimientos Penales de Rusia establece lo siguiente: «Inadmissibility of Disputes Concerning Jurisdiction: The disputes concerning the jurisdiction between the courts shall be inadmissible. Any criminal case, handed over from one court to another in accordance with the procedure, established by Articles 34 and 35 of this Code, shall be taken over in an undisputable order for the proceedings of the court, to which it is passed over». En España, el art. 49 de la Ley Orgánica del Poder Judicial de 1985 precisa que: «Las resoluciones recaídas en la tramitación de los conflictos de competencia no serán susceptibles de recurso alguno, ordinario o extraordinario». En los EE. UU. las decisiones de remand no son apelables, y las de removal sólo lo son excepcionalmente. 
Por ello, en derecho procesal penal la conexión o conexidad constituye un criterio determinante de la competencia y puede definirse como un enlace o vínculo objetivo entre hechos diversos o entre delitos diversos. En teoría hay dos tipos de conexión: la conexión penal en sentido estricto, que se entabla entre hechos o entre delitos, y la conexión procesal, que se refiere al posible enlace o interacción entre los ámbitos jurisdiccionales de dos o más tribunales en función de criterios objetivos.

Igualmente, debo reiterar que conviene tener en cuenta las diferentes características entre los Estados. No es igual la conexidad en sistemas jurisdiccionalmente unitarios (España, Francia, Italia), que en sistemas federales sin dualismo jurisdiccional penal (Alemania, Argentina, Rusia) y en sistemas federales con dualismo jurisdiccional penal (México, EE. UU.). Precisamente, en el apartado próximo examinaré el modelo mexicano. Y por último, vale la pena decir que sólo voy a referirme aquí a la conexidad penal, que plantea problemas distintos a los de la conexidad entre otras jurisdicciones ${ }^{15}$, o aun más complejos en el caso de la conexidad entre la jurisdicción militar y la jurisdicción penal ordinaria ${ }^{16}$.

15 Por ejemplo, entre la jurisdicción administrativa y la jurisdicción laboral. Al respecto puede verse, en el modelo mexicano, la llamada "competencia por afinidad", estudiada por Lucila Silva Guerrero en "Competencia por afinidad en la jurisdicción contencioso-administrativa", disponible en: http://biblio.juridicas.unam.mx/libros/5/2301/18. $p d f$.

16 Por seguir con el modelo mexicano, se planteó el problema de la interpretación extensiva de la jurisdicción militar, en concreto del art. 57 del Código de Justicia Militar, que fue considerado incompatible con la Convención Americana por la Corte IDH en las sentencias Radilla Pacheco de 2009 y Rosendo Cantú y Fernandez Ortega, ambas del año 2010. Una vez operada la reforma constitucional del año 2011 en materia de control de convencionalidad y de derechos humanos, la SCJN, en sentencia dictada en el amparo núm. 133/2012, declaró inconstitucional el art. 57, fracción II, inciso a), del Código de Justicia Militar por considerarlo incompatible con el art. 13 de la Constitución Federal Mexicana, al no garantizar que las víctimas de violaciones de los derechos humanos tengan la posibilidad real y efectiva de someterse a la jurisdicción de un juez o tribunal ordinario. Con carácter general, las reglas de colisión entre la jurisdicción militar y la jurisdicción penal ordinaria suelen atribuir la competencia al juez especial: el art. 78 IV del Código de Procedimiento Penal de Brasil dispone que "no concurso entre a jurisdiçãocomum e a especial, prevalecerá esta», y el art. 60 del Código Procesal Penal de El Salvador señala que: «Cuando exista conexidad entre delitos de competencia común y especializada, el juzgamiento corresponderá a esta última. En este caso, la acumulación no será procedente cuando implique un grave retardo en el procedimiento». En Colombia, el art. 52 del Código de procedimientos penales de 2004 (Ley 906 del 2004) señala que: «Cuando se trate de conexidad entre 
Las normas penales y procesales penales llevan desde hace muchas décadas estableciendo reglas para solucionar los problemas de conexión tanto de hechos y delitos como de competencia judicial. Por ejemplo, el Código Procesal Penal del Perú (2004) dispone lo siguiente:

Artículo 31 Conexión procesal.- Existe conexión de procesos en los siguientes casos:

1. Cuando se imputa a una persona la comisión de varios delitos.

2. Cuando varias personas aparezcan como autores o partícipes del mismo hecho punible.

3. Cuando varias personas vinculadas por una misma voluntad criminal hayan cometido diversos hechos punibles en tiempo y lugar diferentes.

4. Cuando el hecho delictuoso ha sido cometido para facilitar otro delito o para asegurar la impunidad.

5. Cuando se trate de imputaciones recíprocas.

Otros países latinoamericanos regulan la conexidad de manera muy similar. En Venezuela el art. 70 del Código Orgánico Procesal Penal prevé cinco causas de conexión, muy similares a las peruanas ${ }^{17}$. Los arts. 55 del Código Procesal Penal de Guatemala (Decreto 51-92), 50 del Código Procesal Penal de Costa Rica y 51 del Código de Procedimientos Penales de Colombia de 2004,

delitos de competencia del juez penal de circuito especializado y cualquier otro funcionario judicial corresponderá el juzgamiento a aquel». En España, el último apartado del art. 65.1 de la LOPJ de 1985 establece que: «En todo caso, la Audiencia Nacional [órgano especializado en materia de terrorismo o narcotráfico] extenderá su competencia al conocimiento de los delitos conexos con todos los anteriormente reseñados». Venezuela tiene en cambio una regla distinta, pues atribuye la competencia al juez penal ordinario: el art. 75 del Código Orgánico Procesal Penal establece, bajo la rúbrica «Fuero de atracción», que: «Si alguno de los delitos conexos corresponde a la competencia del Juez ordinario y otros a la de jueces especiales, el conocimiento de la causa corresponderá a la jurisdicción penal ordinaria».

17 Venezuela, art. 70: «Son delitos conexos: 1. Aquellos en cuya comisión han participado dos o más personas cuando el conocimiento de las respectivas causas corresponda a diversos tribunales; los cometidos por varias personas, en tiempos o lugares diversos, si han procedido de concierto para ello, o cuando se hayan cometido con daño recíproco de varias personas. 2. Los cometidos como medio para perpetrar otro, para facilitar su ejecución, para asegurar al autor o a un tercero el pago, beneficio, producto, precio ofrecido o cualquiera otra utilidad. 3. Los perpetrados para procurar la impunidad de otro delito. 4. Los diversos delitos imputados a una misma persona. 5. Aquellos en que la prueba de un delito, o de alguna circunstancia relevante para su calificación, influya sobre la prueba de otro delito o de alguna de sus circunstancias». 
establecen cuatro casos de conexión ${ }^{18}$, y en Argentina o El Salvador sólo hay tres casos de conexión ${ }^{19}$. Brasil distingue entre conexión y continencia: el art. 76 del Código de Procedimiento Penal regula la conexión con tres supuestos:

A competência será determinada pela conexão:

I - se, ocorrendo duas ou mais infrações, houverem sido praticadas, ao mesmo tempo, por várias pessoas reunidas, ou por várias pessoas em concurso, embora diverso o tempo e o lugar, ou por várias pessoas, umas contra a outra - conexão intersubjetiva;

18 Guatemala, art. 55: «Habrá conexión 1) Cuando a una misma persona se le imputen dos o más hechos punibles. 2) Cuando los hechos punibles hubieran sido cometidos simultáneamente por varias personas reunidas o, aunque hubieren sido cometidos en distintos lugares o tiempos, si hubiese mediado un propósito común o acuerdo previo. 3) Cuando uno de los hechos punibles imputados hubiera sido cometido para perpetrar o facilitar la comisión de otro, o procurar a un partícipe o a otros el provecho o la impunidad. 4) Cuando los hechos punibles imputados hubieran sido cometidos recíprocamente». El art. 50 de Costa Rica es prácticamente idéntico. El art. 51 colombiano prevé: «Al formular la acusación el fiscal podrá solicitar al juez de conocimiento que se decrete la conexidad cuando: 1 . El delito haya sido cometido en coparticipación criminal. 2. Se impute a una persona la comisión de más de un delito con una acción u omisión o varias acciones u omisiones, realizadas con unidad de tiempo y lugar. 3. Se impute a una persona la comisión de varios delitos, cuando unos se han realizado con el fin de facilitar la ejecución o procurar la impunidad de otros; o con ocasión o como consecuencia de otro. 4. Se impute a una o más personas la comisión de uno o varios delitos en las que exista homogeneidad en el modo de actuar de los autores o partícipes, relación razonable de lugar y tiempo, y, la evidencia aportada a una de las investigaciones pueda influir en la otra».

19 En Argentina el art. 41 del Código Procesal Penal señala que: «Las causas serán conexas en los siguientes casos si: $1^{\circ}$ ) Los delitos imputados han sido cometidos simultáneamente por varias personas reunidas; o aunque lo fueren en distinto tiempo o lugar, cuando hubiere mediado acuerdo entre ellas. $2^{\circ}$ ) Un delito ha sido cometido para perpetrar o facilitar la comisión de otro, o para procurar al autor o a otra persona su provecho o la impunidad. $3^{\circ}$ ) Si a una persona se le imputaren varios delitos». En El Salvador el art. 59 del Código Procesal Penal establece que: «Siempre que no se trate de un hecho de competencia militar los procedimientos serán conexos: 1) Si los hechos imputados han sido cometidos simultáneamente por varias personas reunidas o, aunque hayan sido cometidos en distintos lugares o tiempos, cuando ha mediado acuerdo entre ellas. 2) Si un hecho ha sido cometido para perpetrar o facilitar la comisión de otro, o para procurar al culpable o a otros el provecho o la impunidad. 3) Cuando a una o más personas se les imputen uno o varios hechos, aun cuando hayan sido cometidos en diferentes lugares o sean de distinta gravedad». 
II — se, no mesmo caso, houverem sido umas praticadas para facilitar ou ocultar as outras, ou para conseguir impunidade ou vantagem em relação a qualquer delas conexão objetiva;

III — quando a prova de uma infração ou de qualquer de suas circunstâncias elementares influir na prova de outra infração — conexão instrumental.

Y el art. 77 regula la continencia: «A competência será determinada pela continência quando: I - duas ou mais pessoas forem acusadas pela mesma infração - continência subjetiva II - no caso de infração cometida nas condições previstas nos arts. 70,73 e 74 do Código Penal — continência objetiva».

En España el art. 17 de la Ley de Enjuiciamiento Criminal prevé estos casos de conexión:

Considéranse delitos conexos:

Los cometidos simultáneamente por dos o más personas reunidas, siempre que éstas vengan sujetas a diversos Jueces o Tribunales ordinarios o especiales, o que puedan estarlo por la índole del delito.

Los cometidos por dos o más personas en distintos lugares o tiempos si hubiera precedido concierto para ello.

Los cometidos como medio para perpetrar otros o facilitar su ejecución.

Los cometidos para procurar la impunidad de otros delitos.

Los diversos delitos que se imputen a una persona al incoarse contra la misma causa por cualquiera de ellos, si tuvieren analogía o relación entre sí, a juicio del Tribunal, y no hubiesen sido hasta entonces sentenciados.

Todas estas causas de conexión, referidas a hechos y a delitos, permiten establecer reglas procesales tendentes a racionalizar y unificar el enjuiciamiento de estos delitos. Las normas procesales penales suelen ir seguidas de un artículo en el cual se asigna a uno u otro órgano judicial el conocimiento de estos delitos conexos. Por ejemplo, el Código de Procedimientos Penales de Colombia (2004) prevé los siguientes criterios:

Artículo 52. Competencia por conexidad. Cuando deban juzgarse delitos conexos conocerá de ellos el juez de mayor jerarquía de acuerdo con la competencia por razón del fuero legal o la naturaleza del asunto; si corresponden a la misma jerarquía será factor de competencia el territorio, en forma excluyente y preferente, en el siguiente orden: donde se haya cometido el delito más grave; donde se haya realizado el mayor número de delitos; donde se haya producido la primera aprehensión o donde se haya formulado primero la imputación. Cuando se trate de conexidad entre delitos de competencia del juez penal de circuito especializado y cualquier otro funcionario judicial corresponderá el juzgamiento a aquél. 
En Venezuela, el Código Orgánico Procesal Penal establece sólo reglas bastante sencillas (la territorial y la temporal):

Artículo 71. Competencia. El conocimiento de los delitos conexos corresponde a uno solo de los tribunales competentes. Son tribunales competentes según su orden para el conocimiento de las causas por delitos conexos:

1. El del territorio donde se haya cometido el delito que merezca mayor pena;

2. El que debe intervenir para juzgar el que se cometió primero, en el caso de los delitos que tengan señalada igual pena ${ }^{20}$.

En España, el sistema es muy similar. El art. 18 de la Ley de Enjuiciamiento Criminal dispone también reglas territoriales y temporales:

Son jueces y tribunales competentes, por su orden, para conocer de las causas por delitos conexos:

El del territorio en que se haya cometido el delito a que esté señalada pena mayor.

El que primero comenzare la causa en el caso de que a los delitos esté señalada igual pena.

El que la Audiencia de lo criminal o el Tribunal Supremo en sus casos respectivos designen, cuando las causas hubieren empezado al mismo tiempo, o no conste cuál comenzó primero.

No obstante lo anterior, será competente para conocer de los delitos conexos cometidos por dos o más personas en distintos lugares, si hubiera precedido concierto para ello, con preferencia a los indicados en el apartado anterior, el juez o tribunal del partido judicial sede de la correspondiente Audiencia Provincial, siempre que los distintos delitos se hubieren cometido en el territorio de una misma provincia y al menos uno de ellos se hubiera perpetrado dentro del partido judicial sede de la correspondiente Audiencia Provincial.

En Brasil, el art. 78 del Código de Procedimiento Penal prevé:

Na determinação da competência por conexão ou continência, serão observadas as seguintes regras:

20 En El Salvador el Código Procesal Penal prevé algo muy parecido, pero con una regla añadida. Véase el art. 60: «Cuando exista conexidad entre procedimientos por delitos de acción pública se acumularán y será competente: a) El juez o tribunal que conozca del hecho más grave. b) Si los hechos están sancionados con la misma pena, el juez del lugar en que se cometió el primero. c) Si los hechos son simultáneos o no conste debidamente cuál se cometió primero, el juez que haya prevenido». 
I - no concurso entre a competência do júri e a de outro órgão da jurisdição comum, prevalecerá a competência do júri; Il — no concurso de jurisdições da mesma categoria:

a) preponderará a do lugar da infração, à qual for cominada a pena mais grave;

b) prevalecerá a do lugar em que houver ocorrido o maior número de infrações, se as respectivas penas forem de igual gravidade;

c) firmar-se-á a competência pela prevenção, nos outros casos;

III — no concurso de jurisdiçôes de diversas categorias, predominará a de maior graduação;

IV — no concurso entre a jurisdição comum e a especial, prevalecerá esta.

El Código Procesal Penal de Argentina es igualmente breve en cuanto a estas reglas de reparto competencial, pero introduce una cláusula de cierre muy amplia:

Reglas de conexión:

Art. 42. - Cuando se sustancien causas conexas por delitos de acción pública y jurisdicción nacional, aquéllas se acumularán y será tribunal competente:

1) Aquel a quien corresponda el delito más grave.

2) Si los delitos estuvieren reprimidos con la misma pena, el competente para juzgar el delito primeramente cometido.

3) Si los delitos fueren simultáneos, o no constare debidamente cuál se cometió primero, el que haya procedido a la detención del imputado, o, en su defecto, el que haya prevenido.

4) Si no pudieran aplicarse estas normas, el tribunal que debe resolver las cuestiones de competencia tendrá en cuenta la mejor y más pronta administración de justicia. La acumulación de causas no obstará a que se puedan tramitar por separado las distintas actuaciones sumariales.

Finalmente, en México el art. 475 CFPP, sobre el que más adelante regresaré, regula del modo siguiente la conexidad de delitos:

Los delitos son conexos:

I. Cuando han sido cometidos por varias personas unidas.

II. Cuando han sido cometidos por varias personas, aunque en diversos tiempos y lugares, pero a virtud de concierto entre ellas.

III. Cuando se ha cometido un delito: para procurarse los medios de cometer otro, para facilitar su ejecución, para consumarlo, o para asegurar la impunidad.

En virtud de estas reglas, un juez o tribunal penal atrae el conocimiento de otras causas o delitos conexos. Lo importante de las causas de conexión y de la consiguiente atribución a uno u otro tribunal es que tienen una finalidad racionalizadora evidente. No sólo para dilucidar posibles conflictos de 
competencia, sino sobre todo porque permite la economía procesal (se celebra un juicio en lugar de varios juicios), porque permite evitar sentencias contradictorias (delitos conexos podrían ser absueltos o condenados por distintos tribunales, o hechos declarados probados en una sentencia podrían no serlo en otra sentencia), porque permite preservar la imparcialidad del juez (que no va estar "contaminado" por otras sentencias que hayan recaído anteriormente sobre el mismo hecho o sobre hechos conexos), porque permite una valoración íntegra de todo el material probatorio (que de otra manera estaría disperso o repartido entre dos o más tribunales) y porque facilita el derecho de defensa (al acusado le es más fácil defenderse de una acusación en un proceso que de varias acusaciones en varios procesos).

Sin embargo este fin racionalizador sólo se consigue si los casos de conexión están predeterminados de antemano y si también lo están los criterios de atribución de la competencia jurisdiccional. De poco serviría establecer reglas relativas a la conexión si estas reglas en lugar de racionalizar o aclarar introdujesen más confusión o introdujesen elementos de discrecionalidad en el ejercicio de la jurisdicción penal. Algo de esto encontramos en el antes citado art. 42 Código Procesal Penal de Argentina, que tras establecer reglas de competencia por conexión, prevé una cláusula casi discrecional, basada en conceptos jurídicos indeterminados de gran amplitud («mejor y más pronta administración de justicia»):

Art. 42. - Cuando se sustancien causas conexas por delitos de acción pública y jurisdicción nacional, aquéllas se acumularán y será tribunal competente: [...] 4º) Si no pudieran aplicarse estas normas, el tribunal que debe resolver las cuestiones de competencia tendrá en cuenta la mejor y más pronta administración de justicia.

En el mismo sentido, hay ejemplos de normas que atribuyen una competencia casi discrecional a la hora de excepcionar la competencia. Es el caso de la llamada "transferencia de competencia» que instauró Perú en 1982, con la ley 23414 que permitía llevar un proceso penal de un tribunal a otro en función de «la seguridad de los inculpados». Es cierto que no se trata, técnicamente hablando, de una competencia discrecional, dejada a la libre apreciación de las autoridades, sino de un concepto jurídico indeterminado, pero en realidad ambas cosas están muy próximas. En México existe una ley en materia de delito de secuestro, del año 2010, reglamentaria del art. 73, fracción XXI de la Constitución, que prevé que serán enjuiciados no por la jurisdicción estatal sino por la federal cuando así lo reclame el Ministerio Fiscal atendiendo a apreciaciones prácticamente discrecionales («las características del hecho», «la relevancia social del hecho»): 
Artículo 23. Los delitos previstos en esta Ley se prevendrán, investigarán, perseguirán y sancionarán por la Federación cuando se trate de los casos previstos en la Ley Federal contra la Delincuencia Organizada y cuando se apliquen las reglas de competencia previstas en la Ley Orgánica del Poder Judicial de la Federación y del Código Federal de Procedimientos Penales; o cuando el Ministerio Público de la Federación solicite a la autoridad competente de la entidad federativa, le remita la investigación correspondiente, atendiendo a las características propias del hecho, así como a las circunstancias de ejecución o la relevancia social del mismo.

Continuando con el ordenamiento mexicano, estudiaré a continuación la regulación de la facultad de atracción en lo tocante a delitos contra la libertad de expresión, operada en 2012 y 2013.

\section{LA FACULTAD DE ATRACCIÓN TAL Y COMO RESULTA DE LA REFORMA CONSTITUCIONAL MEXICANA DE 2012, REGLAMENTADA EN EL AÑO 2013 CON LA MODIFICACIÓN DEL ART. 10 DEL CÓDIGO FEDERAL DE PROCEDIMIENTOS PENALES}

Dentro de la teoría procesal penal de la conexidad y de la competencia por conexión existe una vertiente particular. Es la que se ocupa no de la conexidad entre hechos constitutivos de una misma conducta delictiva, sino entre delitos pertenecientes a la jurisdicción federal y a la jurisdicción estatal. Naturalmente, esta circunstancia únicamente se da en aquellos Estados federales con dualidad de jurisdicciones penales como son México o los EEUU, y no se da en Estados federales que sólo tienen una jurisdicción penal y un código penal como son Rusia, Bélgica, Alemania, Argentina, Suiza o Brasil.

No es lo mismo prever que cuando haya conexidad objetiva y predeterminada por la ley el caso pasará a la jurisdicción federal (lo cual introduce cierto automatismo), que prever que cuando se den ciertas circunstancias las autoridades federales "podrán» ejercer la facultad de atracción respecto de ciertos asuntos penales cualificados.

En el primer caso estaríamos más bien en el supuesto de las reglas de conexidad o de la competencia por conexión que se mencionó en apartado anterior: es una asignación por así decir automática, que no supone el ejercicio de ninguna facultad o potestad por parte del poder público, y que en realidad - como ya se dijo- es más bien una federalización general de un tipo de delitos. Sin embargo, como veremos en seguida, en el segundo caso sí se trata de una potestad, facultad o atribución de las autoridades federales, que será más o menos discrecional en función de con cuánto detalle o precisión regule la ley la noción de conexidad. 


\section{Veamos cuál es la previsión del art. 10 CFPP mexicano:}

En los casos de delitos del fuero común cometidos contra algún periodista, persona o instalación, que afecten, limiten o menoscaben el derecho a la información o las libertades de expresión o imprenta, el Ministerio Público de la Federación podrá ejercer la facultad de atracción para conocerlos y perseguirlos, y los jueces federales tendrán, asimismo, competencia para juzgarlos. Esta facultad se ejercerá en los casos de delitos en los que se presuma su intención dolosa y cuando se presente alguna de las siguientes circunstancias:

I. Cuando existan indicios de que en el hecho constitutivo de delito hubiere participado algún servidor público de los órdenes estatal o municipal.

II. Cuando en la denuncia o querella la víctima o el ofendido hubiere señalado como presuntoresponsable a algún servidor público de los órdenes estatal o municipal.

III. Cuando se trate de delitos graves así calificados por la ley.

IV. Cuando la vida o integridad física de la víctima u ofendido se encuentre en riesgo real.

V. Cuando lo solicite la autoridad competente de la entidad federativa de que se trate. VI. Cuando los hechos constitutivos de delito impacten de manera trascendente al ejercicio al derecho a la información o a las libertades de expresión o imprenta.

VII. Cuando en la entidad federativa en la que se hubiere realizado el hecho constitutivo de delito o se hubieren manifestado sus resultados, existan circunstancias objetivas y generalizadas de riesgo para el ejercicio del derecho a la información o las libertades de expresión o imprenta.

VIII. Cuando el hecho constitutivo de delito trascienda el ámbito de una o más entidades federatias.

IX. Cuando por sentencia o resolución de un órgano previsto en cualquier tratado internacional del que el Estado Mexicano sea parte, se hubiere determinado la responsabilidad internacional del Estado Mexicano por defecto u omisión en la investigación, persecución o enjuiciamiento de delitos contra periodistas, personas o instalaciones que afecten, limiten o menoscaben el derecho a la información o las libertades de expresión o imprenta.

En cualquiera de los supuestos anteriores, la víctima u ofendido podrá solicitar al Ministerio Público de la Federación el ejercicio de la facultad de atracción. En los supuestos previstos en las fracciones IV y V o cuando la víctima u ofendido lo solicite, el Ministerio Público de la Federación inmediatamente requerirá a la autoridad local una copia de la investigación respectiva, y una vez recibida deberá determinar si procede o no el ejercicio de la facultad de atracción dentro de las 48 horas siguientes.

Contra la resolución que niegue el ejercicio de la facultad de atracción, la víctima o el ofendido podrá interponer, ante el Procurador General de la República, recurso de reconsideración, dentro de los 15 días hábiles siguientes a la fecha en que se le 
hubiere notificado. El Procurador General de la República, o el servidor público en quien delegue la facultad, deberá resolver el recurso en un término que no excederá de 48 horas hábiles. El recurso de reconsideración tendrá por objeto revocar, modificar o confirmar la resolución relativa al ejercicio de la facultad de atracción. Se tramitará de manera expedita. El silencio del Procurador General de la República, o del servidor público al que se le hubiere delegado esa facultad, constituirá el efecto de confirmar la resolución del Ministerio Público de la Federación.

Para analizar este precepto, lo primero que hay que señalar es que la existencia de la facultad de atracción requiere, como paso previo, que la propia Constitución federal la permita o prevea. Ese es precisamente uno de los problemas que existen en Argentina respecto de la avocación o per saltum: que no aparece prevista en la Constitución (y sólo al cabo del tiempo fue regulada en la ley), y por eso parte de los autores niegan legitimidad a la avocación. En México este problema está adecuadamente resuelto, por la mención expresa del art. 73, fracción XXI, de la Constitución Federal. Fue, pues, necesario reformar la Constitución Federal para poder instaurar esta facultad, lo cual es impecable desde el punto de vista de la técnica jurídica.

En segundo lugar, las causales de la atracción parecen ajustarse a las circunstancias sociales de violencia contra periodistas (o activistas de derechos humanos en ejercicio de su libertad de expresión, que vienen a equipararse a efectos de la aplicación del art. 10 CFPP). Conforme a todos los datos existentes, se dan las circunstancias sociales que justifican la intervención del poder constituyente federal y del poder legislativo federal (insuficiencia o incapacidad de la jurisdicción estatal para hacer frente al castigo de ciertos delitos —en este caso, de los delitos contra periodistas - generando impunidad de los delincuentes e indefensión a las víctimas). Sin duda, dicha realidad no es tan extrema como la que había en países como Colombia o Perú (con zonas tomadas por la guerrilla en las que el poder público había perdido el control, lo cual justificó que ciertos juicios penales no se celebrasen ante el juez del lugar sino que se transfiriesen a tribunales centrales o alejados de las zonas de conflicto). En cualquier caso, la apreciación de tales circunstancias, reflejadas en las nueve causales, es una cuestión de política criminal que es apreciada por el legislador conforme a criterios de oportunidad y conveniencia.

\section{EL EJERCICIO DE LA FACULTAD DE ATRACCIÓN COMO COMPETENCIA DISCRECIONAL}

Se plantea aquí la cuestión de la discrecionalidad en el ejercicio de la facultad de atracción. Sin duda, el Ministerio Público federal tiene, y debe tener, criterios de política criminal en virtud de los cuales le interese más la per- 
secución de unos delitos estatales que la persecución de otros. Sin embargo, se podría sostener que la selección de casos sobre los cuales ejercer la facultad de atracción debería regularse de la manera más clara y objetiva posible para evitar que la decisión se tome en virtud de criterios de mera oportunidad. La discrecionalidad (o sea: la toma de una decisión por una autoridad conforme a criterios de oportunidad o conveniencia poco o nada regulados en una norma) es algo difícil de ejercer, con carácter general, y más aún en materia penal, pues introduce o puede introducir un elemento de arbitrariedad en el castigo que tendencialmente podría ser poco compatible, según se vio, con algunos principios constitucionales y procesales.

Parece pues conveniente que la ley regule las condiciones de ejercicio de esta facultad: requisitos, plazo, competencia, efectos, recurribilidad, etc. Y aquí nuevamente hay que comparar lo que dice la Constitución Mexicana sobre la avocación y lo que dice sobre la facultad de atracción: para la avocación se establecen por lo menos dos criterios generales («interés y trascendencia»), mientras que para la facultad de atracción sólo se habla de "conexidad». En efecto: el art. 107, fracción V, inciso d) y fracción VIII, inciso b), por referencia al art. 103 II y III, regula la avocación que hace la SCJN por vía de amparo, para lo que se requieren los criterios - aparentemente cumulativos en lugar de alternativos- de «interés y trascendencia». En cambio, el art. 73, fracción XXI, sólo habla de conexidad (sin precisar en qué consiste esta), puesto que se limita a señalar que: «Las autoridades federales podrán conocer de los delitos del fuero común, cuando éstos tengan conexidad con delitos federales o delitos contra periodistas, personas o instalaciones que afecten, limiten o menoscaben el derecho a la información o las libertades de expresión o imprenta».

Lo primero que hay que plantearse es cuál de estas dos técnicas (la conexidad, o bien el «interés y trascendencia») deja más margen al legislador a la hora de reglamentar estos dos preceptos constitucionales. La respuesta depende de cómo se conciba la conexidad (si se interpreta ampliamente o por el contrario se interpreta restrictivamente), y también de si se considera que el legislador debe concretar los criterios constitucionales de «interés y trascendencia» o, por el contrario, puede ceñirse a reiterarlos, no añadiendo nada a ellos. En teoría, la técnica procesal de la conexidad limita más el margen de discrecionalidad, porque consiste en la existencia de una conexión objetiva o de una relación entre delitos federales y delitos estatales. De manera que el legislador tiene en teoría un margen más amplio a la hora de regular la avocación, porque la facultad de atracción estaría condicionada a la existencia de circunstancias objetivas de conexidad.

En realidad la existencia o no de motivos o de circunstancias habilitantes previstas en la ley no sería demasiado relevante porque lo que se está regulan- 
do en el art. 10 CFPP es una decisión discrecional y no una decisión reglada o automática. Los criterios o circunstancias en él previstos sólo habilitan a la autoridad federal para decidir si atrae o no el delito, pero le dejan libertad para hacerlo o no. En efecto: del tenor literal tanto de la Constitución como del art. 10 CFPP (ambos emplean el término "podrá») y también de la indeterminación de algunas de las circunstancias previstas en el art. 10 CFPP, es bastante evidente que se trata de una decisión discrecional ${ }^{21}$. En este escenario, las nueve causales del referido precepto, repito, juegan el siguiente papel: si no se da ninguna de ellas, no hay atracción posible, pero si se dan, la atracción es facultativa y no obligatoria.

En relación con esta opción legislativa de establecer una potestad discrecional, cabe por lo menos preguntarse si no podría tal vez convertir en inoperante la facultad de atracción. Si la ley se limita a "permitir» (en lugar de obligarle) que el Ministerio Público la ejerza, y esta decisión no se somete a criterios objetivos u objetivables, bastará con que el Ministerio Público decida no ejercerla para que no se produzca atracción ninguna; o bastará con que cambie el Gobierno, o la jerarquía del Ministerio Público, o que sin cambiar pero los mismos responsables adopten distintos lineamientos de política criminal, para que quede desactivada o desvirtuada la previsión de atracción. Al ser una decisión discrecional, tan legítimo sería un uso excesivo de la facultad de atracción como un no uso de la misma - quedando en este segundo caso frustrada la voluntad del legislador de atraer los casos, o algunos de ellos, a la jurisdicción federal.

Es preciso plantearse también si es recurrible la decisión del Ministerio Público de no ejercitar la facultad de atracción. La respuesta que dio el legislador es positiva: cabe que quien esté interesado en la atracción (según la ley, sólo la víctima del delito) así lo solicite a la Procuraduría, y si la atracción se deniega, podrá interponerse recurso de reconsideración que resolverá en 48 horas la PGR, estableciéndose un criterio de silencio negativo (la falta de respuesta equivale a la confirmación de la decisión inicial denegadora de la atracción). No parece ser posible oponerse a la decisión de atracción: el art. 10 CFPP sólo prevé recurso contra la denegación de la atracción, y la participación de las autoridades estatales o locales en la decisión de atracción es sólo a título de iniciativa (causal V: la facultad de atracción se ejercerá «cuando lo solicite la autoridad competente de la entidad federativa de que se trate»). No es descabellado considerar que alguna de las partes (el acusado del delito

21 No me parece que el imperativo «ejercerá», empleado en el primer párrafo del art. 10 CFPP, deba interpretarse como creador de una obligación de ejercicio de la facultad de atracción, que se vendría a oponer al «podrá» de la frase que le precede. 
o las autoridades policiales estatales o la procuraduría estatal) quiera oponerse a la atracción por considerar que no se dan las causales establecidas y, por tanto, que el asunto debe permanecer en la jurisdicción estatal. El legislador, al reglamentar la fracción XXI del art. 73 de la Constitución Federal, no ha querido establecer un sistema contradictorio o simétrico, sino que establece una especie de "presunción de atracción", y no permite ni las alegaciones de las partes ni tampoco el recurso contra la decisión de atracción (únicamente se da participación a la víctima, en forma de solicitud de atracción y de recurso de reconsideración $)^{22}$. Ello es una opción legislativa comprensible, puesto que se desea facilitar la atracción y permitir la intervención de la jurisdicción federal, pero podría plantear algún problema de garantías para las demás partes.

\section{EL ART. 10 DEL CÓDIGO FEDERAL DE PROCEDIMIENTOS PENALES COMO SUPUESTO DE ATRACCIÓN SIN CONEXIDAD}

Como sabemos, el art. 73, fracción XXI, de la Constitución, tal y como se reformó en 2012, atribuye a «las autoridades federales» la posibilidad (no la obligación) de enjuiciar delitos estatales «cuando estos tengan conexidad con los delitos federales». Ello parece indicar que la facultad de atracción se supedita a la existencia de conexión o conexidad con delitos federales.

Veamos cuáles son estas circunstancias de conexidad, a las que me he referido con carácter general en el apartado anterior. Las regulan con carácter general los arts. 6 a 10 y 475 del CFPP:

Artículo 6.- Es tribunal competente para conocer de un delito, el del lugar en que se comete, salvo lo previsto en los párrafos segundo, tercero y quinto del artículo 10. Si el delito produce efectos en dos o más entidades federativas, será competente el juez de cualquiera de éstas o el que hubiera prevenido; pero cuando el conflicto involucre como partes a indígenas y no indígenas, será tribunal competente el que ejerza jurisdicción en el domicilio donde radique la parte indígena.

Artículo 7.- En los casos de los artículos 2o, 40 y 5o., fracción V, del Código Penal, será competente el tribunal en cuya jurisdicción territorial se encuentre el inculpado; pero si éste se hallare en el extranjero, lo será para solicitar la extradición, instruir y fallar el proceso, el tribunal de igual categoría en el Distrito Federal, ante quien el Ministerio Público ejercite la acción penal.

22 La posición de las autoridades estatales es singular: conforme a la causal V, pueden instar de la Procuraduría federal que ejerza la atracción, pero en caso que esta la deniegue no pueden recurrir la decisión, ni tampoco oponerse en ningún momento a la decisión de ejercer la facultad de atracción. 
Artículo 8.- En los casos de las fracciones I y II del artículo 5o del Código Penal, es competente el tribunal a cuya jurisdicción corresponda el primer punto del territorio nacional adonde arribe el buque; y en los casos de la fracción III del mismo artículo, el tribunal a cuya jurisdicción pertenezca el puerto en que se encuentre o arribe el buque.

Artículo 9.- - Las reglas del artículo anterior son aplicables, en los casos análogos, a los delitos a que se refiere la fracción IV del mismo artículo 5o. del Código Penal.

Artículo 10.- Es competente para conocer de los delitos continuados y de los continuos o permanentes, cualquiera de los tribunales cuyo territorio aquéllos produzcan efectos o hayan realizado actos constitutivos de tales delitos.

En caso de concurso de delitos, el Ministerio Público Federal será competente para conocer de los delitos del fuero común que tengan conexidad con delitos federales, y los jueces federales tendrán, asimismo, competencia para juzgarlos.

Artículo 475. Los delitos son conexos:

I. Cuando han sido cometidos por varias personas unidas.

II. Cuando han sido cometidos por varias personas, aunque en diversos tiempos y lugares, pero a virtud de concierto entre ellas.

III. Cuando se ha cometido un delito: para procurarse los medios de cometer otro, para facilitar su ejecución, para consumarlo, o para asegurar la impunidad.

Sin embargo, la regulación de la facultad de atracción que hizo el legislador federal al modificar el art. 10 CFPP en el Decreto de 25 de abril de 2013 publicado en el Diario Oficial de la Federación el 3 de mayo del mismo año no contempla un sistema de conexidad sino un sistema distinto. Así lo dice literalmente el propio legislador, por ejemplo, en el Dictamen de la Comisión de Derechos Humanos de la Cámara de Diputados, de 24 de abril de 2013 sobre la reglamentación del art. 73, fracción XXI, de la Constitución que se convertiría en el recién referido nuevo art. $10 \mathrm{CFPP}^{23}$. En dicho Dictamen se sostiene de manera inequívoca que la principal aportación de la reglamentación, que la Comisión considera positiva, es que prescinde del criterio de la conexidad. La razón para ello, implícita en el Dictamen, es que se entiende que la conexidad es una técnica más restrictiva o limitada que deja menos margen al trasvase de casos a la jurisdicción federal, de manera que se prefirió optar por un modelo que permita que los casos sean más fácilmente atraídos y enjuiciados por la jurisdicción federal. El mismo criterio se deduce de opinio-

23 Disponible en: http://gaceta.diputados.gob.mx/Gaceta/62/2013/abr/20130425-IV.html\#DecDictamen1. 
nes manifestadas por otros diputados en iniciativas legislativas posteriores ${ }^{24}$. Es decir, la reforma del art. 10 CFPP respecto de los delitos contra la libertad de expresión, en reglamentación del art. 73, fracción XXI, de la Constitución, no se basa en la existencia de alguna de las recién mencionadas circunstancias de conexidad con delitos federales, sino en la presencia de circunstancias y requisitos expresamente definidos por el legislador que son del todo ajenas a los delitos federales y que no se refieren al entrecruzamiento fáctico o normativo (concurso de delitos, o de territorios, o de simultaneidad, etc.).Veámoslo.

Analizando las nueve causales del art. 10 CFPP, se constata que sólo una de ellas responde a la técnica de la conexidad: la numero VIII («Cuando el hecho constitutivo de delito trascienda el ámbito de una o más entidades federativas»), y eventualmente también la número IX ("Cuando por sentencia o resolución de un órgano previsto en cualquier tratado internacional del que el Estado Mexicano sea parte, se hubiere determinado la responsabilidad internacional del Estado Mexicano por defecto u omisión en la investigación, persecución o enjuiciamiento de delitos contra periodistas, personas o instalaciones que afecten, limiten o menoscaben el derecho a la información o las libertades de expresión o imprenta») en la medida en que introduciría en el hecho delictivo la responsabilidad internacional de la nación. Todas las demás causales se basan en hechos objetivos sin conexidad procesal o delictiva con la jurisdicción federal.

De manera que el art. $10 \mathrm{CFPP}$, en lo referente a los delitos contra la libertad de expresión, en realidad no regula la conexidad entre delitos estatales y delitos federales ni tampoco el traspaso a la jurisdicción federal de la investigación y enjuiciamiento de aquellos delitos en los que concurran las circunstancias de conexidad. Regula otra cosa bastante distinta, en la que no se requieren elementos fácticos de conexidad sino circunstancias objetivas como la intencionalidad (dolo), la gravedad del hecho, el riesgo para el ejercicio del derecho a la información, el así solicitarlo la autoridad estatal, etc. Ninguna de

24 Véase por ejemplo la iniciativa del proyecto de decreto que reforma el art. 10 del Código Federal de Procedimientos Penales y que adiciona el art.21 del Código Nacional de Procedimientos, suscrita en diciembre de 2014 por la diputada Miriam Cárdenas Cantú, del grupo parlamentario del PRI: http://sil.gobernacion.gob.mx/Archivos/Documentos/2014/12/asun_3192414_20141222_1419267199.pdf). En esta iniciativa, la diputada Cárdenas Cantú considera igualmente muy positivo que «fuesen en 2013 incorporados los párrafos quinto, sexto, séptimo y octavo al artículo 10 del CFPP, en los cuales se establece la facultad de atracción del Ministerio Público de la Federación respecto de aquellos delitos del orden común, que sin ser conexos a ilícitos federales, sean cometidos contra periodistas, personas o instalaciones vulnerando el derecho a la información o las libertades de expresión o imprenta» (la cursiva es mía). 
ellas está relacionada con los delitos federales o con multiplicidad territorial, delictiva o de autoría, y por tanto no constituyen supuestos de conexidad.

Parece que el legislador mexicano quiso deliberadamente continuar la línea de otras reformas procesales en las que se atraía igualmente a la jurisdicción federal otro tipo de delitos sin basarse en elementos de conexidad. Por ejemplo, la antes mencionada federalización de los delitos de secuestro operada en el año $2010^{25}$, que establece un sistema doble o alternativo: el caso pasa a la federación cuando se apliquen las reglas de competencia o conexidad de la LOPJF o del CFPP, o bien «cuando el Ministerio Público de la Federación solicite a la autoridad competente de la entidad federativa, le remita la investigación correspondiente, atendiendo a las características propias del hecho, así como a las circunstancias de ejecución o la relevancia social del mismo» ${ }^{26}$.

Una vez constatado que el art. 10 CFPP no contempla un modelo de conexidad, conviene plantearse un problema que me parece complejo. Se trata de preguntarse si el legislador, a la hora de reglamentar la reforma del art. 73, fracción XXI, de la Constitución, promulgando en 2013 la facultad de atracción del art. 10 CFPP, se ajustó o no a la previsión constitucional. Para ello el punto de partida es la constatación de que, ciertamente, el legislador disponía de un amplio margen para desarrollar la fracción XXI del art. 73, pero esta parece requerir que la atracción (que no se menciona expresamente en dicha fracción XXI del art. 73 de la Constitución) se produzca cuando haya cone$x_{i d a d}{ }^{27}$. Es decir: la Constitución requeriría necesariamente la concurrencia del

25 Ley general para prevenir y sancionar los delitos en materia de secuestro, reglamentaria de la fracción XXI del art. 73 de la Constitución política de los Estados Unidos Mexicanos (publicada en el Diario Oficial de la Federación el 30 de noviembre de 2010).

26 Art. 23 de la referida ley en materia de delitos de secuestro: «Los delitos previstos en esta Ley se prevendrán, investigarán, perseguirán y sancionarán por la Federación cuando se trate de los casos previstos en la Ley Federal contra la Delincuencia Organizada y cuando se apliquen las reglas de competencia previstas en la Ley Orgánica del Poder Judicial de la Federación y del Código Federal de Procedimientos Penales; o cuando el Ministerio Público de la Federación solicite a la autoridad competente de la entidad federativa, le remita la investigación correspondiente, atendiendo a las características propias del hecho, así como a las circunstancias de ejecución o la relevancia social del mismo».

27 Recordemos el tenor literal de la fracción XXI del art. 73 de la Constitución: «Las autoridades federales podrán conocer también de los delitos del fuero común, cuando éstos tengan conexidad con delitos federales o delitos contra periodistas, personas o instalaciones que afecten, limiten o menoscaben el derecho a la información o las libertades de expresión o imprenta». 
elemento de la conexidad, de manera que para que entre en juego la jurisdicción federal respecto de los delitos cometidos contra periodistas sería preciso que se de la conexión con delitos federales y, sin embargo, la ley regula las causales de la atracción sin prever la conexidad o conexión con delitos federales ${ }^{28}$.

¿Significa esto que el art. 10 CFPP es inconstitucional? En puridad, existe una contradicción entre la fracción XXI del artículo 73 y el art. 10 CFPP. Tal contradicción se podría salvar diciendo que cuando la Constitución habla de «conexidad» no se está refiriendo a la noción estricta o técnica de conexidad procesal, y que por tanto el legislador disponía de un margen mayor y no estaba obligado a reglamentar la facultad de atracción utilizando el concepto de conexidad tal y como se deriva de la teoría procesal. En todo caso, parecería que el legislador de 2013 habría ido más allá de lo que parecía prever el constituyente de 2012.

En realidad, la necesidad de que los poderes públicos — singularmente las autoridades federales - se dotaran de herramientas para perseguir y castigar los delitos contra los periodistas primó sobre los problemas de estricta técnica normativa. La celeridad de las reformas (en apenas un año se reformó la Constitución Federal y se aprobó la reglamentación) obedece, sin duda, a la urgencia por combatir la gravísima situación de violencia contra periodistas ${ }^{29}$. En este contexto, el legislador federal interpretó que la reforma constitucional de 2012 le dejaba un margen de actuación más amplio de lo que el tenor literal de la nueva fracción XXI del art. 73 ofrecía porque parecía requerir el elemento de la conexidad para que se pudiese dar la facultad de atracción. Que ello sea una solución constitucionalmente admisible y que, al margen de ello, las reformas resulten verdaderamente eficaces en la prevención y el castigo de los delitos contra periodistas, es algo que el tiempo dirá.

\section{BIBLIOGRAFÍA}

Báez Silva, C. y Cienfuegos Salgado, D. (2009). El per saltum en el derecho procesal electoral federal. Boletin Mexicano de Derecho Comparado, 126, 1201-1236.

Córdoba Castroverde, D. (2000). Algunas cuestiones relativas al derecho fundamental al juez ordinario predeterminado por la ley. Cuadernos de Derecho Público, 10, 89-112.

Escalada López, M. L. (2007). Sobre el juez ordinario predeterminado por la ley. Valencia: Tirant lo Blanch.

28 Mejor dicho: la conexidad sólo aparece en dos de las nueve causales del art. 10 CFPP.

29 Véanse las estadísticas más recientes en Freedom House México (2015). 
- (2011). Algunas aplicaciones del derecho fundamental a la predeterminación legal del juez: procedimiento administrativo sancionador, procedimiento arbitral y otras cuestiones. Revista General de Derecho Procesal, 25, 1.

Freedom House México. (2015). Informe de libertad de prensa 2015. Disponible en: https:// www.freedomhouse.org/publicaciones/informe-libertad-de-prensa-2015-m-xico\#. Vbh3trPtlBc.

Haro, R. (2001). El per saltum en la justicia federal argentina. Anuario Iberoamericano de Justicia Constitucional, 5, 183-205.

Rizo Gómez, B. (2006). La tendencia legislativa a la improrrogabilidad de la competencia territorial. Revista General de Derecho Procesal, 9, 1-22.

- (2014). El derecho al juez ordinario predeterminado por la ley y la predeterminación de la competencia. Principios que deben inspirar toda reforma competencial del sistema judicial español. Diario La Ley, 8372, 2. 